\title{
Peningkatan Kemampuan Komunikasi dan Self-Efficacy Matematis Siswa melalui Pendekatan Pembelajaran Matematika Realistik
}

\author{
1Sakinah Ubudiyah Siregar, ${ }^{1}$ Amin Harahap, ${ }^{2}$ Sri Milfayetti, ${ }^{2} I b n u$ Hajar \\ ${ }^{1}$ Program Studi Pendidikan Matematika, Universitas Labuhan Batu, Jl. Sisingamangaraja, Labuhan \\ Batu, Sumatera Utara, 21415 Indonesia \\ ${ }^{2}$ Fakultas Ilmu Pendidikan Universitas Negeri Medan, Jl. Ismail Harun No.55, Deli Serdang, Sumatera \\ Utara 20371 Indonesia \\ *Corresponding Author e-mail: sakinah.ubudiyah@yahoo.com
}

Received: April 2020; Revised: May 2020; Published: July 2020

\begin{abstract}
Abstrak
Penelitian ini bertujuan untuk mengetahui peningkatan kemampuan komunikasi dan self-efficacy matematis siswa melalui pendekatan pembelajaran matematika realistik (PMR). Penelitian ini menggunakan pendekatan penelitian kuantitatif dengan metode eksperimen semu. Sampel yang digunakan pada penelitian masing-massing yaitu 30 siswa (kelas eksperimen) dan 30 siswa (kelas kontrol) sekolah dasar di beberapa sekolah sekitar kota Rantauprapat. Hasil penelitian ini menunjukkan bahwa (1) peningkatan kemampuan komunikasi matematis siswa yang diberi pendekatan realistik lebih tinggi daripada siswa yang diberi pembelajaran konvensional, (2) adanya interaksi antara pendekatan pembelajaran dengan kemampuan awal siswa terhadap peningkatan kemampuan komunikasi matematis dan self-efficacy matematis, dan (3) proses penyelesaian komunikasi matematis siswa yang menggunakan pendekatan pembelajaran matematika realistik lebih baik dari pendekatan konvensional. Berdasarkan hasil penelitian dapat disimpulkan bahwa PMR lebih baik dari pendekatan matematika konvensional dalam meningkatkan kemampuan komunikasi dan self-efficacy matematis siswa.
\end{abstract}

Kata Kunci: Kemampuan Komunikasi, Self-Efficacy, Pendekatan Matematika Realistik

\section{Improvement of Students' Mathematical Communication Skills and Self-Efficacy through the Realistic Mathematics Learning Approach}

\begin{abstract}
This study aims to determine the improvement of students' mathematical communication skills and self-efficacy through a realistic mathematics learning approach (PMR). This research uses a quantitative research approach with quasi-experimental methods. The samples used in each research were 30 students (experimental class) and 30 students (control class) in elementary schools in several schools around the city of Rantauprapat. The results of this study indicate that (1) an increase in mathematical communication skills of students who are given a realistic approach is higher than students who are given conventional learning, (2) there is an interaction between learning approaches with students' initial ability to improve mathematical communication skills and mathematical self-efficacy, and (3) the process of solving students' mathematical communication using a realistic mathematics learning approach is better than the conventional approach. Based on the results of the study it can be concluded that PMR is better than conventional mathematical approaches in improving students' mathematical communication skills and self-efficacy.
\end{abstract}

Keywords: Communication Skills, Self-Efficacy, Realistic Mathematical Approach

How to Cite: Siregar, S., Harahap, A., Milfayetti, S., \& Hajar, I. (2020). Peningkatan Kemampuan Komunikasi dan Self-Efficacy Matematis Siswa melalui Pendekatan Pembelajaran Matematika Realistik. Jurnal Penelitian dan Pengkajian Ilmu Pendidikan: e-Saintika, 4(2), 151-159. doi:https://doi.org/10.36312/e-saintika.v4i2.207 


\section{PENDAHULUAN}

Perkembangan ilmu pengetahuan dan teknologi memungkinkan semua pihak dapat memperoleh informasi dengan cepat dan mudah dari berbagai sumber. Selain perkembangan yang pesat, perubahan juga terjadi dengan cepat. Karenanya diperlukan kemampuan untuk memperoleh, mengelola dan memanfaatkan informasi untuk bertahan pada keadaan yang selalu berubah, tidak pasti dan kompetitif. Kemampuan ini membutuhkan pemikiran, antara lain berpikir sistematis, logis, kritis yang dapat dikembangkan melalui tujuan pembelajaran matematika (Van de Walle, 2008).

Mata pelajaran matematika di sekolah dasar dan juga tingkat menengah bertujuan mengacu pada Kurikulum 2006 yaitu (1) memahami konsep matematika, menjelaskan keterkaitan antar konsep dan mengaplikasikan konsep atau algoritma, secara luwes, akurat, efisien, dan tepat, dalam komunikasi, (2) menggunakan penalaran pada pola dan sifat, melakukan manipulasi matematika dalam membuat generalisasi, menyusun bukti, atau menjelaskan gagasan dan pernyataan matematika, (3) memecahkan masalah yang meliputi kemampuan komunikasi, merancang model matematika, menyelesaikan model dan menafsirkan solusi yang diperoleh, (4) mengkomunikasikan gagasan dengan simbol, tabel, diagram, atau media lain untuk memperjelas keadaan atau masalah, dan (5) memiliki sikap menghargai kegunaan matematika dalam kehidupan, yaitu memiliki rasa ingin tahu, perhatian, dan minat dalam mempelajari matematika, serta sikap ulet dan percaya diri dalam pemecahan masalah (BSNP, 2006).

Mata pelajaran bidang studi matematika bertujuan untuk menunjukkan bahwa peran matematika merupakan salah satu mempersiapkan anak didik untuk sanggup menghadapi keadaan pada perubahan atau tantangan dalam hidup dan perkembangan di dunia. Oleh karena itu dilakukan pelatihan- pelatihan melalui pembuatan keputusan dan kesimpulan dengan pemikiran secara cermat, jujur, efisien dan efektif logis, rasional, kritis. Selain itu, anak didik diharapkan dapat menggunakan bidang studi matematika dan bagaimana cara berpikir matematika yang baik dan benar, keterampilan dalam penerapan matematika dalam mempelajari berbagai ilmu pengetahuan yang menyangkut pada penalaran matematika dan pembentukan sikap percaya diri anak didik.

Kecakapan matematika penting ditumbuhkan anak didik dalam pembelajaran matematika seperti koneksi, dan pemecahan masalah, penalaran, komunikasi dan kecakapan hidup (life skill) yang sangat dibutuhkan anak didik dalam keadaan sekarang ini. Lima standar proses pada prinsip-prinsip dan standar dari NCTM salah satunya yaitu komunikasi (Van de Walle, 2008). Komunikasi dapat membantu sisswa dalam pembelajaran mengetahui konsep matematika yang baru ketika anak didik menggunakan menggambar, memberikan laporan dan penjelasan verbal, menggunakan objek. Juga ketika menggunakan diagram, menulis dan menggunakan simbol matematika. Kesalahan pada jawaban dapat diidentifikasi dan ditunjukkan. Keuntungannya adalah dapat mengingatkan anak didik bahwa mereka mempunyai tanggungjawab dengan gurupada pembelajaran.

Dari prinsip-prinsip dan standar NCTM yang dikemukakan, dapat dikatakan kemampuan komunikasi matematis juga merupakan hal yang sangat penting dan perlu ditingkatkan dalam pembelajaran matematika untuk meningkatkan hasil belajar matematika. Aspek komunikasi melatih siswa untuk dapat mengkomunikasikan gagasan, baik komunikasi lisan maupun tulisan. Ansari (2009) menyatakan bahwa komunikasi matematik baik sebagai aktifitas sosial (talking) 
maupun sebagai alat bantu berfikir (writing) adalah kemampuan yang mendapat rekomendasi para pakar agar terus ditumbuh kembangkan dikalangan siswa.

lebih lanjut Ansari (2009) mendefinisikan pengertian prinsip dan standar komunikasi matematik sebagai alat komunikasi (mathematics as cummunication) merupakan pengembangan bahasa dan simbol untuk mengkomunikasikan ide matematik, sehingga siswa dapat: "(1) mengungkapkan dan menjelaskan pemikiran mereka tentang ide matematik dan hubungannya, (2) merumuskan definisi matematik dan membuat generalisasi yang diperoleh melalui investigasi (penemuan), (3) mengungkapkan ide matematik secara lisan dan tulisan, (4) membawa wacana matematik dengan pemahaman, (5) menjelaskan dan mengemukakan serta memperluas pertanyaan terhadap matematika yang telah dipelajarinya, (6) menghargai keindahan dan kekuatan notasi matematik, serta peranannya dalam mengembangkan ide/gagasan matematik.

Kesenjangan penelitian pada aspek kognitif, dan kesenjangan aspek afektif mulai ditelaah para peneliti, diantaranya Self-Efficacy (kepercayaan diri) yang merupakan dapat meningkatkan kemampuan matematika siswa. Teori kognitif sosial oleh Bandura (2006) menyatakan bahwa self-efficacy merupakan suatu komponen kunci di dalam kognitif sosial. Kepercayaan diri pada seseorang, dalam menggunakan kemampuannya untuk berhasil melaksanakan tugas yang dikerjakannya. Hal ini dapat ditemukan pada self-efficacy yang merupakan suatu faktor penentu pilihan utama untuk pengembangan individu, ketekunan dalam menggunakan diberbagai kesulitan, dan pemikiran mempola dan reaksi-reaksi secara emosional yang mereka alami. Self-Efficacy dapat dibangkitkan dari diri siswa melalui empat sumber, yaitu (1) pengalaman otentik (authentic mastery experiences), (2) pengalaman orang lain (vicarious experience), (3) pendekatan sosial atau verbal (verbal persuasion), (4) aspek psikologi (physiological affective states).

Tuntutan pengembangan kemampuan Self-Efficacy tertulis dalam kurikulum metematika antara lain menyebutkan bahwa pelajaran matematika harus menanamkan sikap menghargai kegunaan matematika dalam kehidupan, yaitu memiliki rasa ingin tahu, perhatian, dan minat dalam mempelajari matematika, serta sikap ulet dan percaya diri, dan kemampuan komunikasi (Ansari, 2009).

Pada pembelajaran matematika, guru diharuskan dapat memilih pendekatan dan strategi pembelajaran yang sesuai dalam pembelajaran dan dikaitkan dengan tahap perkembangan intelektual anak, oleh karena itu strategi dan pendekatan ini harus mempengaruhi hasil belajar anak. Banyak diketahui dalam ketika guru mengajar kebanyakan anak pada awal masuk Ssekolah dasar belajar mulai dari situasi-situasi nyata atau dari contoh-contoh paling mendekati bergerak ke konsep nyata yang lebih umum. Dengan itu, guru kurang tepat memulai konsep melalui definisi. Namun, akan lebih bewhasil apabila memulainya dengan mengenalkan sesuatu benda-benda yang sering dilihat anak didik dengan benda anak akan mencoba berkomunikasi dan hal seperti ini dapat membiasakan anak didik lebih mengamati dan memaknai suatu objek hingga pada akhirnya pada pemahaman.

Pendekatan pembelajaran yang sesuai dengan perubahan anak didik salah satunya adalah pendekatan Pembelajaran Matematika Realistik (PMR). PMR merupakan pendekatan dalam pembelajaran matematika yang memandang matematika sebagai suatu aktivitas manusia. Pernyataan ini berangkat dari pendapat Fruedenthal bahwa matematika merupakan aktivitas insani dan harus dikaitkan dengan realitas (Turmudi, 2008). Pembelajaran matematika tidak dapat dipisahkan dari sifat matematika seseorang memecahkan masalah, mencari masalah, dan 
mengorganisasi atau matematisasi materi pelajaran.

Pertimbangan menggunakan PMR dapat juga dilihat dari beberapa penelitian seperti Manurung (2009), Saragih (2007), Risnanosanti (2010), Saragih (2011), Afriati (2011) dan Hasibuan (2011) yang secara keseluruhan hasil penelitian tersebut diperoleh kesimpulan bahwa PMR lebih baik dari pendekatan matematika biasa yang menggunakan perbedaan kemampuan atau keterampilan matematika dengan penelitian ini. Berdasarkan uraian tersebut, penulis melakukan penelitian dengan menerapkan kemampuan komunikasi dan self-efficacy matematis siswa SD melalui pendekatan pembelajaran matematika realistik. Diharapkan peningkatan kemampuan komunikasi dan self-efficacy siswa dengan pendekatan pembelajaran matematika realistik lebih baik daripada kemampuan komunikasi matematika siswa dengan pendekatan konvensional, adanya interaksi antara pendekatan pembelajaran dengan kemampuan awal siswa terhadap peningkatan kemampuan komunikasi matematis dan self-efficacy matematis, proses penyelesaian komunikasi matematis siswa yang menggunakan pendekatan pembelajaran matematika realistik lebih baik dari pendekatan konvensional.

Penelitian ini bertujuan untuk mendeskripsikan kemampuan komunikasi, selfefficacy, dan proses penyelesaian jawaban siswa yang dipengaruhi oleh pendekatan pembelajaran yaitu Pembelajaran Matematika Realistik (PMR) dan Pembelajaran Matematika Konvensional (PMK). Langkah-langkah PMR dalam penelitian ini merujuk pada pendapat Saragih (2011) yaitu (1) Memahami masalah kontekstual; (2) Menjelaskan masalah kontekstual; (3) Menyelesaikan masalah kontekstual; (4) Membandingkan dan mendiskusikan jawaban; (5) Menyimpulkan.

\section{METODE}

Penelitian yang digunakan merupakan pendekatan penelitian kuantitatif dengan metode eksperimen dalam bentuk kuasi eksperimen (Ruseffendi, 2005). Sampel yang digunakan dua kelas dari SD Negeri 112134 yaitu IV A dan IV B untuk kelas eksperimen dengan jumlah 30 orang dan dua kelas dari SD Negeri 116874 Rantauprapat yaitu kelas IV A dan IV B untuk kelas kontrol berjumlah 30 orang. Kelas eksperimen diberikan PMR, dan kelas kontrol akan diberikan pembelajaran konvensional.

Intrumen-intrumen dalam penelitian ini terdiri dari tiga instrumen yaitu (1) instrumen yang digunakan untuk mengukur self-efficacy dalam penelitian ini berdasarkan indikator level, generality, strength (Bandura, 2006), (2) instrument kemampuan komunikasi memiliki indikator representasi (representing), mendengar (listening), membaca (reading), diskusi (discussing), menulis (writing) (Ansari, 2009), dan (3) interaksi antar pembelajaran dengan gender menggunakan instrument dengan indikator Corrected Model, Intercept, pembelajaran dan gender (Hasratuddin, 2013).

Kriteria proses penyelesaian masalah kemampuan komunikasi matematis dalam penelitian ini adalah (1) Rapi, langkah-langkah berurutan, penyelesaian benar, Rapi, langkah-langkah tidak berurutan, penyelesaian benar; (2) Rapi, langkah-langkah berurutan, penyelesaian tidak benar; (3) Rapi, langkah-langkah tidak berurutan, penyelesaian tidak benar; (5) Tidak rapi, langkah-langkah berurutan, penyelesaian benar; (6) Tidak rapi, langkah-langkah tidak berurutan, penyelesaian benar; (7) Tidak rapi, langkah-langkah berurutan, penyelesaian tidak benar; (8) Tidak rapi, langkahlangkah tidak berurutan, penyelesaian tidak benar; (9) Tidak menjawab (Hasratuddin, 
2013).

Data yang dianalisis adalah skor kemampuan komunikasi matematis dan skor self-efficacy. Data yang diperoleh dengan mengelompokkan menurut kelompok pembelajaran pendekatan realistik dan konvensional dan gender laki-laki dan perempuan. Uji persyaratan statistik yang digunakan sebagai dasar dalam pengujian hipotesis, antara lain uji normalitas dan homogenitas varians, menghitung gain ternormalisaasi. Kemudian melakukan uji ANAVA dua jalur.

\section{HASIL DAN PEMBAHASAN}

\section{Kemampuan Komunikasi dan Self-Efficacy Matematis}

Kemampuan komunikasi matematis merupakan kesanggupan anak didik dalam menyampaikan pesan matematika dengan tertulis, dalam penelitian ini diambil beberapa aspek, yaitu menuliskan informasi dari pernyataan ke dalam model matematika, menginterpretasikan gambar ke dalam pernyataan, menyatakan ide matematika dalam bentuk gambar, menjelaskan prosedur penyelesaian (Bandura, 2006).

Perhitungan yang diperoleh bahwa peningkatan kemampuan komunikasi matematis siswa yang diberi pendekatan realistik lebih tinggi daripada siswa yang diberi pembelajaran konvensional. Dalam mengikuti pembelajaran dengan pendekatan realistik telah terbiasa aktif dalam menyelesaikan masalah berpikir secara individual untuk mendapatkan konsep yang baik. Proses pembelajaran pembelajaran matematika realistic bukan hanya sekedar mentransfer ilmu dari guru kepada siswa, melainkan suatu proses yang dikondisikan atau diupayakan oleh guru, sehingga siswa aktif dengan berbagai cara membangun sendiri pengetahuannya. Sejalan dengan Piaget yang menekankan pada pentingnya motivasi dan fasilitasi siswa oleh guru Agar perkembangan intelektual anak dapat berlangsung dengan optimal maka mereka perlu dimotivasi dan difasilitasi untuk membangun teori-teori yang menjelaskan tentang dunia sekitar. Dalam pendekatan realistik guru dituntut memfasilitasi dan mendorong siswa untuk terlibat aktif dalam proses pembelajaran sehingga mereka mampu mengkonstruksi pengetahuan bagi dirinya.

Hasil penelitian yang diperoleh dengan rata-rata skor pretes dan postes kemudian dihitung peningkatan ( $N$-Gain) kedua kelas, kelas yang diberi pendekatan realistik maka diperoleh rerata skor $N$-Gain 0,731 dengan simpangan baku 0,080 dan untuk pembelajaran yang diberi pembelajaran konvensional diperoleh rerata skor $N$ Gain 0,550 dengan simpangan baku 0,054.

ANAVA dua jalur yang diperoleh dengan menggunakan skor N-Gain kelompok pendekatan realistik dan pembelajaran konvensional maka diperoleh nilai $\mathrm{F}$ faktor pembelajaran sebesar 100,123 dan taraf signifikan 0,000. Karena signifikan 0,000<0,05 berarti $H_{0}$ ditolak dengan demikian dapat disimpulkan bahwa peningkatan kemampuan komunikasi matematis siswa dengan pendekatan realistik lebih tinggi daripada siswa yang diberikan pembelajaran konvensional.

\section{Interaksi Antara Pendekatan Pembelajaran dengan Kemampuan Awal Siswa}

Kemampuan siswa juga diperoleh berdasarkan gender dengan mengelompokkan siswa didasarkan pada gender laki-laki dan wanita. Gender yang digunakan dengan mengkaitkan Faktor gender dengan faktor pembelajaran. Dapat dilihat pada Tabel 1 berikut. 
Tabel 1. Pendekatan pembelajaran dengan gender terhadap peningkatan kemampuan komunikasi matematis siswa

Tests of Between-Subjects Effects

Dependent Variable: N_GAIN

\begin{tabular}{|c|c|c|c|c|c|c|}
\hline Source & & $\begin{array}{l}\text { Type III } \\
\text { Sum of } \\
\text { Squares }\end{array}$ & Df & $\begin{array}{c}\text { Mean } \\
\text { Square }\end{array}$ & $\mathrm{F}$ & Sig. \\
\hline Corrected Model & &, $514^{\mathrm{a}}$ & 3 & ,171 & 37,906 & ,000 \\
\hline Intercept & & 22,057 & 1 & 22,057 & 4880,572 & ,000 \\
\hline PEMBELAJARAN & & ,453 & 1 & ,453 & 100,123 &, 000 \\
\hline GENDER & & ,015 & 1 & ,015 & 3,322 &, 07 \\
\hline $\begin{array}{l}\text { PEMBELAJARAN } \\
\text { GENDER }\end{array}$ & * & ,004 & 1 & 004 & ,837 & ,3 \\
\hline Error & & ,253 & 56 & ,005 & & \\
\hline Total & & 25,379 & 60 & & & \\
\hline Corrected Total & & 767 & 59 & & & \\
\hline
\end{tabular}

Dari hasil analisis perhitungan faktor pembelajaran yang berkaitan dengan gender diperoleh 0,837 dan taraf signifikan 0,364. Karena taraf signifikan 0,364>0,05 maka $H_{0}$ diterima yang artinya tidak terdapat interaksi antara faktor pendekatan pembelajaran dengan gender siswa terhadap peningkatan kemampuan komunikasi matematis siswa. Penelitian ini menunjukkan bahwa pembelajaran mempunyai pengaruh terhadap kemampuan komunikasi matematis siswa, sedangkan jika dihubungkan dengan gender tidak mempengaruhi kemampuan komunikasi matematis siswa.

Penelitian ini sejalan dengan penelitian yang dilakukan oleh Hasratuddin (2013) yang menyatakan tidak terdapat interaksi antara pembelajaran dengan gender terhadap kemampuan berpikir kritis siswa. Perbedaan peningkatan kemampuan berpikir kritis lebih dipengaruhi oleh pembelajaran daripada gender.

\section{Proses Penyelesaian Komunikasi Matematis Siswa}

Hasil tes kemampuan komunikasi matematis dari proses penyelesaian siswa baik siswa yang diajarkan dengan pembelajaran matematika realistik maupun pembelajaran biasa dapat dilihat dalam Tabel 2 berikut.

Tabel 2. Kriteria proses penyelesaian masalah kemampuan komunikasi matematis

\begin{tabular}{|c|c|c|c|c|c|c|c|c|c|c|c|}
\hline \multirow{3}{*}{ No } & \multirow{3}{*}{ Kriteria } & \multicolumn{5}{|c|}{$\begin{array}{c}\text { Tipe Pembelajaran } \\
\text { Matematika Realistik }\end{array}$} & \multicolumn{5}{|c|}{$\begin{array}{l}\text { Pembelajaran } \\
\text { Konvensional }\end{array}$} \\
\hline & & \multicolumn{5}{|c|}{ Butir soal } & \multicolumn{5}{|c|}{ Butir soal } \\
\hline & & 1 & 2 & 3 & 4 & 5 & 1 & 2 & 3 & 4 & 5 \\
\hline 1 & $\begin{array}{l}\text { Rapi, langkah-langkah } \\
\text { berurutan, penyelesaian benar }\end{array}$ & 12 & 8 & 7 & 1 & 10 & 6 & 3 & 3 & 0 & 0 \\
\hline 2 & $\begin{array}{l}\text { Rapi, langkah-langkah tidak } \\
\text { berurutan, penyelesaian benar } \\
\text { Rapi, langkah-langkah }\end{array}$ & 3 & 2 & 2 & 10 & 4 & 2 & 1 & 4 & 5 & 2 \\
\hline 3 & $\begin{array}{l}\text { berurutan, penyelesaian tidak } \\
\text { benar }\end{array}$ & 3 & 4 & 4 & 2 & 3 & 5 & 7 & 8 & 6 & 3 \\
\hline 4 & $\begin{array}{l}\text { Rapi, langkah-langkah tidak } \\
\text { berurutan, penyelesaian tidak }\end{array}$ & 4 & 3 & 3 & 4 & 3 & 5 & 5 & 4 & 7 & 4 \\
\hline
\end{tabular}




\begin{tabular}{|c|c|c|c|c|c|c|c|c|c|c|c|}
\hline \multirow{3}{*}{ No } & \multirow{3}{*}{ Kriteria } & \multirow{2}{*}{\multicolumn{5}{|c|}{$\begin{array}{c}\text { Tipe Pembelajaran } \\
\text { Matematika Realistik }\end{array}$}} & \multicolumn{5}{|c|}{$\begin{array}{l}\text { Pembelajaran } \\
\text { Konvensional }\end{array}$} \\
\hline & & & & & & & \multicolumn{5}{|c|}{ Butir soal } \\
\hline & & 1 & 2 & 3 & 4 & 5 & 1 & 2 & 3 & 4 & 5 \\
\hline & benar & & & & & & & & & & \\
\hline 5 & $\begin{array}{l}\text { Tidak rapi, langkah-langkah } \\
\text { berurutan, penyelesaian benar }\end{array}$ & 2 & 6 & 5 & 5 & 3 & 0 & 1 & 0 & 2 & 2 \\
\hline 6 & $\begin{array}{l}\text { Tidak rapi, langkah-langkah } \\
\text { tidak berurutan, penyelesaian } \\
\text { benar }\end{array}$ & 0 & 0 & 1 & 0 & 0 & 0 & 1 & 2 & 2 & 1 \\
\hline 7 & $\begin{array}{l}\text { Tidak rapi, langkah-langkah } \\
\text { berurutan, penyelesaian tidak } \\
\text { benar }\end{array}$ & 1 & 2 & 2 & 3 & 3 & 4 & 4 & 2 & 3 & 0 \\
\hline 8 & $\begin{array}{l}\text { Tidak rapi, langkah-langkah } \\
\text { tidak berurutan, penyelesaian } \\
\text { tidak benar }\end{array}$ & 2 & 2 & 3 & 2 & 1 & 5 & 5 & 1 & 2 & 3 \\
\hline 9 & Tidak menjawab & 0 & 0 & 0 & 0 & 0 & 0 & 0 & 0 & 0 & 12 \\
\hline
\end{tabular}

Dari Tabel 2 di atas dapat dilihat bahwa untuk tes kemampuan komunikasi matematis untuk butir 1 siswa yang diajarkan dengan tipe pembelajaran matematika realistik kriteria terbesar sebanyak 12 siswa $(44,4 \%$ dari 27 siswa) yang memenuhi kriteria rapi, langkah-langkah berurutan dan penyelesaian benar, sedangkan siswa yang diajarkan dengan pembelajaran biasa hanya 6 siswa (22,2\% dari 27 siswa) dan merupakan kriteria terbesar untuk pembelajaran biasa pada butir 1. Sedangkan, butir soal 2 untuk siswa yang diajarkan dengan pembelajaran matematika realistik ada 8 siswa (29,6\% dari 27 siswa) yang memenuhi kriteria rapi, langkah-langkah berurutan dan penyelesaian benar dan merupakan kriteria terbesar, sedangkan siswa yang diajarkan pembelajaran biasa hanya 3 siswa (11,1\% dari 27 siswa), pada pembelajaran biasa kriteria terbanyak pada kriteria rapi, langkahlangkah berurutan dan penyelesaian tidak benar sebanyak 7 siswa $(25,9 \%$ dari 27 siswa).

Kriteria untuk butir soal 3 siswa yang diajarkan dengan pembelajaran matematika realistik kriteria terbesar sebanyak 7 siswa $(25,9 \%$ dari 27 siswa) yang memenuhi kriteria rapi, langkah-langkah tidak berurutan dan penyelesaian benar, sedangkan siswa yang diajarkan pembelajaran biasa hanya 3 siswa (11,1\% dari 27 siswa). Pembelajaran biasa kriteria terbesar sebanyak 8 siswa $(29,6 \%$ dari 27 siswa) yang memenuhi kriteria rapi, langkah-langkah berurutan dan penyelesaian tidak benar. Butir soal 4 untuk siswa yang diajarkan dengan pembelajaran matematika realistik hanya 1 siswa (3,70\% dari 27 siswa) yang memenuhi kriteria rapi, langkahlangkah berurutan dan penyelesaian benar, sedangkan untuk pembelajaran biasa tidak ada. Untuk tipe pembelajaran matematika realistik kriteria terbanyak yang memenuhi kriteria rapi, langkah-langkah tidak berurutan dan penyelesaian benar sebanyak 10 siswa $(37,03 \%$ dari 27 siswa), sedangkan pembelajaran biasa kriteria terbanyak sebanyak 7 siswa (25,9\% dari 27 siswa) yang memenuhi kriteria rapi, langkah-langkah tidak berurutan dan penyelesaian tidak benar.

Kriteria butir soal 5 siswa yang diajarkan pembelajaran matematika realistik ada 10 siswa (37,03\% dari 27 siswa ) yang memenuhi kriteria rapi, langkah-langkah berurutan dan penyelesaian benar dan merupakan kriteria terbesar, sedangkan di kelas pembelajaran biasa tidak ada. Untuk pembelajaran biasa kriteria terbanyak sebanyak 12 siswa (44,4\% dari 27 siswa) yang tidak menjawab. 
Berdasarkan lembar jawaban siswa, berikut ini akan disajikan proses penyelesaian kemampuan komunikasi matematis untuk setiap butir soal. Lebih lengkapnya berikut ini disajikan "hasil tes kemampuan komunikasi matematis yang dikategorikan kedalam indikator butir soal yaitu: menuliskan situasi atau ide-ide matematika ke dalam gambar, menjelaskan secara tertulis gambar ke dalam ide matematika, merumuskan ide matematika ke dalam model matematika, dan menjelaskan prosedur penyelesaian.

\section{KESIMPULAN}

Siswa mulai dari pendidikan dasar mengerti akan proses dalam komunikasi dan kepercayaan diri (Self-Efficacy) siswa dapat ditanamkan dengan baik. Peningkatan kemampuan komunikasi dan self-efficacy matematis siswa yang memperoleh pendekatan pembelajaran matematika realistik ini akan dilakukan melalui studi kajitindak terhadap subjek penelitian yaitu siswa SD di beberapa sekolah sekitar kota Rantauprapat.

\section{SARAN}

Untuk penelitian selanjutnya hendaknya menggunakan kemampuan matematika berbeda seperti kemampuan pemahaman, penalaran, koneksi, dan representasi matematis dan secara terperinci dan melakukan penelitian di tingkat sekolah yang berbeda dengan menggunakan pendekatan matematika realistik pada pokok bahasan yang berbeda.

\section{UCAPAN TERIMA KASIH}

Penelitian ini diselesaikan berkat dukungan dan bantuan dari berbagai pihak seperti (1) Kemenristekdikti, (2) Ketua Yayasan Labuahan Batu, (3) Ketua STKIP Labuhan Batu, (4) Ketua STKIP Labuhan Batu, dan (5) para pimpinan sekolah dasar di daerah Labuhan Batu, yang telah memberikan izin melakukan penelitian ini.

\section{DAFTAR PUSTAKA}

Afriati, V. (2011). Peningkatan Pemahaman Konsep dan Komunikasi Matematika Siswa dengan Pendekatan penemuan Terbimbing Berbantuan Software Autograph. Program Pascasarjana UNIMED.

Ansari, B. . (2009). Komunikasi Matematik (Yayasan Pena, Ed.). Banda Aceh.

Bandura, A. (2006). Guide for constructing self-efficacy scales. Self-Efficacy Beliefs of Adolescents. https://doi.org/10.1017/CBO9781107415324.004

BSNP. (2006). Standar Isi untuk Satuan Pendidikan Dasar dan Menengah Standar Kompetensi dan Kompetensi Dasar SD/MI (Depdiknas, Ed.). Jakarta.

Hasibuan, E. . (2011). Pengaruh Pendekatan Matematika Realistik Terhadap Kemampuan Pemecahan Masalah dan Komunikasi Matematis Siswa. Pascasarjana Universitas Negeri Medan.

Hasratuddin, H. (2013). Meningkatkan Kemampuan Berpikir Kritis Siswa SMP Melalui Pendekatan Matematika Realistik. Jurnal Pendidikan Matematika. https://doi.org/10.22342/jpm.4.2.317.

Manurung, R. . (2009). Meningkatkan Kemampuan Penalaran Formal dalam Pembelajaran Matematika SMP dengan Pendekatan Pembelajaran Matematika Realistik. Pascasarjana Universitas Negeri Medan.

Risnanosanti. (2010). Senior High School Student's Ability in Mathematical Creative Thinking and Self Efficacy in Inquiry Learning. Disertasi tidak diterbitkan. 
Bandung: Sekolah Pascasarjana Universitas Pendidikan Indonesia.

Ruseffendi, E. . (2005). Pengantar kepada Membantu Guru Mengembangkan Kompetensinya dalam Pengajaran Matematika untuk Meningkatkan CBSA. Bandung: Tarsito.

Saragih, R. M. (2011). Peningkatan Kemampuan Pemecahan Masalah Matematika Siswa Melalui Pendekatan Matematika Realistik. Sekolah Pascasarjana Universitas Negeri Medan.

Saragih, S. (2007). Mengembangkan Kemampuan Berpikir Logis dan Komunikasi Matematik Siswa Sekolah Menengah Pertama Melalui Pendekatan Matematika Realistik. Sekolah Pasca Sarjana UPI Bandung.

Turmudi. (2008). Landasan Filsafat dan Teori Pembelajaran Matematika (Berparadigma Eksploratif dan Investigatif). Jakarta: PT Leuser Cita Pustaka.

Van de Walle, J. (2008). Pengembangan Pengajaran Matematika Sekolah Dasar dan Menengah (6 Jilid I). Jakarta: Erlangga. 